\title{
Optimism Aspects in Edgar Albert Guest's Poems: Figurative Language Analysis Approach
}

\author{
Irma Rahmawati ${ }^{1}$ \\ \{irma.rahmawati@undira.ac.id ${ }^{1}$ \} \\ English Department, Faculty of Economy and Business, Dian Nusantara University, \\ West Jakarta, Jakarta, Indonesia ${ }^{1}$
}

\begin{abstract}
The writer writes this research entitled "Optimism Aspects in Edgar Albert Guest's Poems: Figurative Language Analysis Approach" to find out aspects of optimism through figurative languages used in Guest's poems since they are very empowering people to not give up easily. The problems in this research discuss about what kinds of figurative language used in the poems, how to find the optimism aspects in the poems, and how to interpret the meaning of the poems. The aims of this research are to find out and interpret the message behind the poems using figurative language. The writer uses qualitative method to do the research. The writer uses 3 Guest's poems It Couldn't be Done, Can't, and See it Through to conduct the research.[1] [2][3] After reading all of poems, the writer notices that the poems have the optimism aspects, especially since they are very inspiring people to keep moving on with life.
\end{abstract}

Keywords: poem, optimism aspects, figurative language

\section{Introduction}

Literature, in essence, describes the values of a society. Literary work is created due to the influence of social and cultural circumstances. Although good literature in general does not directly describe the specific values, but the aspirations of the people inevitably are reflected in literary works. For example, a literature writer may write anything in his/her mind, ideas, experience, and values which can be useful for the readers and their cultural development. However, one may still not understand then ask, "What is literature? And what is its relation between society and literature?" Jean-Paul Sartre implied that literature is an abstract writing with the intention for the readers to interpret it creatively, as far as their imagination goes [4].

Therefore, literature cannot be separated from culture and society. Society is a group of people that live in a same territory and interact with one another while sharing the differences in their customs. Society definitely plays a part in literature. Literary agents could be influenced if he/she lives in a certain society, thus they will be reflected in their writing either intentionally or not. For example, O Captain! My Captain!, written by an American poet, Walt Whitman, is a sad poem about the death of American President Abraham Lincoln and Whitman's sadness due to the death of his idol.

In this research, the writer analyzes the poems by a famous American poet, Edgar Albert Guest. Edgar Albert Guest, also known as Eddie Guest was an English-born American poet who was popular in the first half of the 20th century and became known as "People's Poet". Guest's poems are mostly about sentimental yet optimistic point of view and empowering people to not give up easily. Many people love his poems and Guest stated that he was "a newspaperman who wrote verse for folks." which earned him the title "People's Poet." 
The writer wants to focus on optimism aspects in several of Guest's poem and exploit the meaning behind it by looking at figurative languages contained in the poems. Guest's poems are mostly about sentimental yet optimistic point of view and inspiring people to never stop halfway when doing something and always be responsible with everything that has been done. The writer thinks his poems are interested to be analyzed. The analysis will use positive psychology theory from Martin P. Seligman [5] by analyzing figurative language used in the poem.

\section{Literature Review}

\subsection{Poetry and Poem}

Poetry is one of literature writing, an art of writing that uses aesthetic and rhythmic qualities of language to express one's feeling through figurative language. Spiegelman defined the poetry as an art of naming, and this naming is done by story-telling and by metaphorical approximations and refinements [6]. There are several meanings about poetry according to famous poets. Percy Bysshe Shelley stated in his essay, A Defence of Poetry (1821), which Poetry may be defined to be 'the expression of the imagination' and poetry is closely related with the origin of man [7].

Poem is a finished work written by a poet, one who writes poems, that uses sounds and images he/she wants to show figuratively. Mark Yakich, A lecturer from Loyola University New Orleans, in his article in The Atlantic (2013), "A poem helps the mind play with its welltrod patterns of thought, and can even help reroute those patterns by making us see the familiar anew". [8]

\subsection{Optimism}

The concept of optimism often linked with a German philosopher, Gottfried Wilhelm von Leibniz, who stated that people live in the best of all possible worlds that God could have created. Analysis, religion is viewed as an optimistic illusion. It is an illusion necessary to control aggressiveness and sexual instinct of society. The most common rhetorical expression used to determine whether a person is optimistic or pessimistic is a glass with water at the halfway point [9].

Optimism is not a rediscovery of the "power of positive thinking." Optimism skills do not come from joyful events. Those skills do not include how to say positive things to oneself. Positive statements made only for oneself do not have significant effect. Using the power of positive thinking, it is imperative to know what you will do when you fail. Altering bad things to good things he or she say to oneself when one experiences any kind of hardships in life is the main skill of optimism [5].

People with high optimism also have a sense of pessimism. It is unknown whether pessimism is one of nature's mistakes or it has an important value in certain conditions. Pessimism is needed to support one's realism because in life, blind optimism is not good when one does not think any realistic ways when facing a challenge. Seligman stated that a successful life may needs both optimism and at least occasional pessimism. Pessimism can heighten one's sense of reality in a world filled with unexpected and frequent disasters [5].

\subsection{Figurative Language}

Figurative language is a language formed with words or expressions that is different from the literal meaning. Figurative language often used when one is unable to find words which, 
used in their literal and conventional sense, will adequately express our meaning. The use of figurative language requires to abstract meaning beyond "physical" words. It is about being capable of inferring information beyond syntax or semantics. Figurative language is usual in poetry and prose, as well as non-fiction writing [10].

\section{Personification}

Personification is a figurative language that gives a non-human/inanimate objects a human or animal attributes. It is used to create an understanding of an inanimate things since it is easier for human to understand by using human or animal traits, thus creates a new look at the world from different yet creative perspective beside human perspective [10].

For example, William Blake in his poem "Two Sunflowers in The Yellow Room" wrote:

"Ah, William, we're weary of the weather,"

Said the sunflower, shining in dew.

"Our traveling habits have tired us.

Can you give us a room with a view?"

In this poem, the sunflowers are made as if they were talking to the poet. They asked the poet to move them to a room with different view than the place they were on.

\section{Metaphor}

Metaphor is a word or phrase that is used differently from normal use to explain something, comparing two different, contrasting things that could create similarities or new perspectives. It makes an implicit, implied or hidden comparison between two things that are unrelated but share some common characteristics. It is useful to enrich audience's imagination by appealing to their senses to grasp the meaning and comprehend of what was written or spoken in literary works [11].

The following example of metaphor as follows:

"For him?" shouted Snape. "Expecto Patronum!"

From the tip of his wand burst the silver doe. She landed on the office floor, bounded once across the office, and soared out of the window. Dumbledore watched her fly away, and as her silvery glow faded he turned back to Snape, and his eyes were full of tears.

"After all this time?"

"Always," said Snape."

- Harry Potter and the Deathly Hallows by J. K. Rowling

The silver doe is a metaphor in this line. It represents the grace, strength and beauty of Lily Potter as seen by Snape since he has always loved her, although they are not together.

\section{Simile}

Simile is a figurative language in which things are compared using the words "like" or "as". Unlike metaphor, the things being compared are only said to be like one another, not exactly the same as in metaphor. Simile allows readers to relate the feelings of a writer or a poet to their personal experiences. It inspires life-like quality in our daily talks and in the characters of fiction or poetry. In formal prose, simile is a device both of art and explanation, comparing an unfamiliar thing to some familiar things such as objects, events, processes, etc. known to the reader. [11]

This is an example of a simile in 1984, a novel written by George Orwell:

"In the far distance a helicopter skimmed down between the roofs, hovered for an instant like a bluebottle, and darted away again with a curving flight"

1984 by George Orwell

The book 1984 written by Orwell is not exactly published the same as his entitled novel. It is written in 1949 when helicopters are still not widely used and in its early development. 
Orwell describes a helicopter like a bluebottle fly, an insect that has agile movement; thus, giving a meaning that helicopter is a fast aircraft.

\section{Repetition}

Repetition is one of the oldest literary devices, especially in poetry, that repeats the same words or phrases a few times, and intensifies the subject matter in a poem to make an idea clearer. The device could be repeating word, phrase or a poetical line to focus on its significance in the poem. A poem with repetition can give audience the ability to decipher and understand the meaning behind the poem. There are many types of repetition such as Anaphora, Anadiplosis, Epiphora, and Polyptoton. These words can help embellish sentences to create striking effects. In fact, it happens when the grammatical meaning can be expressed by using syntactical construction instead of morphological marking. It enhances the meaning of a word persuasively and dramatically in writing or speech by employing a cognate of the words. It is also used to create rhetorical effect by the articulation of a speech or statement. [11]

\section{Alliteration}

Alliteration is the use of same letter or sound at the beginning of words that occurs closely together. Alliteration always found in daily life, usually for the name of a company such as Coca-cola, Dunkin' Donuts, or PayPal. In poetry or prose, alliteration is used to make melodious effect that build up the pleasure of reading it. It makes reading and recitation of the poems attractive and appealing; thus, making them easier to learn by heart. Alliteration makes a poem or prose become attractive and easier to understand the meaning of it. [11]

An example of alliteration used in a literature is:

ONCE upon a midnight dreary, while I pondered, weak and weary,

Over many a quaint and curious volume of forgotten lore,-

While I nodded, nearly napping, suddenly there came a tapping.

- $\quad$ The Raven by Edgar Allan Poe

Poe uses alliteration with an implying meaning. It helps the poet to tell the story with a rhythm that creates suspense feeling bigger.

\section{Hyperbole}

Hyperbole is a way of speaking or writing that makes something sound better, more exciting, more dangerous, etc. than it really is. It involves an exaggeration of ideas for the sake of emphasis, surprise, or humor. Hyperbole is a counterpart of understatement, which make the situation become less important. In formal writing the hyperbole must be clearly intended as an exaggeration, and should be carefully restricted. [12]

Hyperbole in literature has serious implications. A writer or poet makes ordinary human behavior becomes wonderful and emotional up to the point that such behavior is not ordinary. This figurative language is used to catch the audience's interest.

This example of hyperbole will be explained under:

"Well now, one winter it was so cold that all the geese flew backward and all the fish moved south and even the snow turned blue. Late at night, it got so frigid that all spoken words froze solid afore they could be heard. People had to wait until sunup to find out what folks were talking about the night before."

- $\quad$ Babe The Blue Ox by Paul Bunyan

Bunyan uses hyperbole and exaggerates that winter can freeze words at night and they have to wait until sunrise before they can speak to each other. 


\section{Imagery}

Imagery is a use of figure of speech to represent objects, actions and ideas by appealing to human senses. Imagery in literature is a guide used for a poet or writer to show the audience around his or her literary works. Imagery is not always necessarily visual, but also sensory, meaning that a poet or writer must use human's five senses to create images that can invoke an attractive response in the audience [10].

\section{Methods}

The researcher is interested to analyze poems and chooses the optimism aspect in the poems by Edgar Albert Guest. The writer uses qualitative method to analyze the poem. Methods involve in this research are that the researcher has visited some libraries around Jakarta and Depok to get more relevant data about the study, utilized the bibliographies from reference books, and looked for the figurative languages to find the meaning of the poems.

This research uses three poems from Edgar Albert Guest, Can't, It Couldn't be Done, See It Through, as the primary data.

There are some ways the researcher has done to accomplish this study. Due to a qualitative research, the researcher did a lot of library research in the libraries to get the qualified data. In addition to books, the Internet access also plays a major role in process of finding relevant data about the poem. The researcher also utilizes the bibliographies from reference books to get more extensive information. Several books from the library were also used to help the researcher since books are more credible in its information.

The first thing the researcher did was reading the poems. In addition to read the poems, the researcher also reads many previous researches which particularly have analyzed a poem. Each poem is identified into different type of figurative languages. After finding the figurative language in the poems, the researcher interpreted the message of the poems, especially on its optimism aspect. The next step was the writer focused on library research. The researcher also explores more sources any bibliography that found in the books. From the bibliography, the writer made use of internet access to get more sources. Finally, the writer comes to conclusion after done with the analysis.

\section{Discussion and Result}

The first poem that the writer analyzed is "Can't". Guest, the poet, writes the first stanza of the poem mostly in figurative language.

Can't is the worst word that's written or spoken

Doing more harm here than slander and lies;

The first line contains hyperbole from the word "the worst word that's written or spoken". It emphasizes the word "Can't" as if the poet thought that word was worse than slander and lies. In common sense, "Can't" does not really have any good or bad elements. It cannot be denied that words may influence people. This line also shows the pessimism of its poet. It can be described that he thought only the bad element of the word "Can't". The bad element here can be shown in the second line that states "Can't" can be more harmful than slander and lies. In this case, 'the power of positive thinking' is needed to alter bad thing into good thing. Pessimism may enclose to the failure. Pessimism always surrounds people. Even people with high optimism also have a bit of pessimism in their lives. Pessimism may support the realism we so 
often need. In many arenas of life, optimism is unwarranted [5]. However, by knowing how often the optimism happens in real life, it may also grow up the pessimism into one's life. That is why optimism sometimes is warranted.

On it is many a strong spirit broken,

And with it many a good purpose dies.

The lines above are personification. Guest gives human qualities to the word "can't" so it could break a strong spirit and killed good purpose. He made it as if "Can't" is something that could kills both "strong spirit" and "good purpose". Although this line draws more about pessimism than optimism, but the implied meaning of optimism is still can be found in the text. By saying Can't, Guest may feel depressed of being fail. That is why he fights against it by saying the bad effects of the word Can't which may free him from the pessimism. Optimism can protect us from against depression and it is far more pleasant mental state to be in. Thus, an understanding of how an individual's sense of personal control determines his fate [5].

It springs from the lips of the thoughtless each morning

And robs us of courage we need through the day.

If the lines above are combined, it becomes a sentence with personification. Can't is not able to literally become alive and robs something, also the word courage is not a physical thing that can be taken. These lines show the other bad effects of Can't. Bad events may make people to be easily depressed. This will soon cause the pessimism and way to test whether pessimism is a cause is to change pessimism to optimism [5]. However, Guest shows optimism aspect by implying Can't as a cause that put people at risk of Can't.

It rings in our ears like a timely-sent warning

And laughs when we falter and fall by the way.

The first line filled with simile because the simile is a figurative language in which things are compared using the words "like" or "as" and as an effort to reconcile the different things. This can be shown the line in rings in our ears like a timely-sent warning which can reconcile the meaning. While the second line filled with personification from the word 'laughs'. However a word cannot laugh as human usually did.

Can't is the father of feeble endeavor, The parent of terror and half-hearted work;

The two lines above filled with metaphor. Metaphor is a comparison of two different things by speaking of one in terms of the other [11]. In this case, the word can't is represented as father and parent. Can't is the father of feeble endeavor, the parent of terror and half-hearted work is a metaphor because can't is not even a person, let alone be a parent or father. However, the similar characteristic in it is that can't can bring forth the feeling of feeble endeavor, terror and half-hearted work.

It weakens the efforts of artisans clever,

And makes of the toiler an indolent shirk.

It poisons the soul of the man with a vision,

It stifles in infancy many a plan;

It greets honest toiling with open derision

And mocks at the hopes and the dreams of a man.

The lines above filled with personification. It can be seen from the pronoun 'it' which refers to Can't. However, Can't cannot do such things like weaken, poison, stifle and does not have a mouth to say greeting, and mocking. Guest personified "Can't" by giving it the distinct human qualities.

Can't is a word none should speak without blushing;

To utter it should be a symbol of shame;

Ambition and courage it daily is crushing;

It blights a man's purpose and shortens his aim. 
There are two figurative languages example here. First, Can't contains metaphor which compares it as a symbol of shame. Guest portrayed a word as being something else. As in this case, a symbol of shame is implied to the word Can't that if it is being said then it will lead to the shame. Second, Can't contains personification which personifies the ambition and courage that can crush, blight, and shorten human attributes.

Despise it with all of your hatred of error;

Refuse it the lodgment it seeks in your brain;

The lines above filled with hyperbole. Hyperbole can be defined as the most overused and overdone rhetorical figure in the whole world which sounds like an exaggeration. Nevertheless, hyperbole still has a rightful and useful place in art and letters if people can use it in right way [11]. The use of hyperbole can be noticed in the pronoun 'it' as the hatred of terror and the lodgement in human's brain which sounds exaggerating and it is not possible in real life.

Arm against it as a creature of terror,

And all that you dream of you some day shall gain.

The words as a creature of terror employ simile. It can be seen a comparison being drawn by using as. Simile is a comparison between two different things that resemble each other in at least one way. Thus, when it compares a noun to a noun, the simile is usually introduced by like and when a verb or phrase is compared to a verb or phrase, as is used [11].

Can't is the word that is foe to ambition,

An enemy ambushed to shatter your will;

Its prey is forever the man with a mission

The lines above filled with metaphor. Guest personified Can't as a foe or enemy. Those lines demonstrate Guest's belief that Can't is very dangerous, like a foe, that can be able to destroy people's ambition and mission.

And bows but to courage and patience and skill.

This line filled with personification. It can be seen from the word bows that personifies Can't. However, bow depicts a human characteristic of an action that cannot be done by just a word.

Hate it, with hatred that's deep and undying,

For once it is welcomed 'twill break any man;

The use of hyperbole can be found in the first line above. Guest felt that Can't should be hated in deep and undying. He believed that Can't is a word that should not be said or it will break any man as in the second line. However, the second line filled with personification because Can't is a word that cannot welcome anything.

Whatever the goal you are seeking, keep trying

And answer this demon by saying: "I can."

The use of metaphor can be found in the word this demon. Guest portrayed Can't as a demon to describe the bad things that would be happened if people say it. However, the term demon is used as an evil thing that can lead someone to do something bad. That is why, Guest imply Can't as a word that affects human's life badly and it should be changed by saying I can.

\section{Conclusion}

In this research, the Writer analyzes poetry by finding figurative languages used in poems. Figurative language contains a language that has meaning more than just one. The Writer uses poems written by Edgar Albert Guest. His poems contain a lot of optimism aspects. For that reason, the Writer analyzes optimism aspects found in the poems by analyzing meaning from figurative languages used by Guest. According to the Writer's analysis, Guest's poems contain 
various figurative languages such as hyperbole, personification, simile, metaphor, imagery, alliteration, and repetition.

Many poets create poems by describing human's life or the environment. As has been analyzed, Guest's poems have many optimism aspects. In general, putting optimism in literature is made to encourage the audience's self-esteem, increase their creativity in doing something, and to give positive attitude for the audience.

\section{References}

[1] Guest EA, "See It Through by Edgar Albert Guest [Internet]. Poetry Foundation. Poetry Foundation;" https://www.poetryfoundation.org/poems/44318/see-it-through (accessed Sep. 20, 2020).

[2] Guest EA, . "It Couldn't Be Done by Edgar Albert Guest [Internet]. Poetry Foundation. Poetry Foundation;" https://www.poetryfoundation.org/poems/44314/it-couldnt-be-done (accessed Sep. 20, 2020).

[3] Guest EA, “Can’t by Edgar Albert Guest [Internet]. by Edgar Albert Guest - Famous poems, famous poets. - All Poetry." https://allpoetry.com/poem/8471321-Cant-by-Edgar-Albert-Guest (accessed Sep. 20, 2020).

[4] J.-P. Sartre, "What is literature?” and other essays. Harvard University Press, 1988.

[5] M. E. P. Seligman, Learned optimism: How to change your mind and your life. Vintage, 2006.

[6] W. Spiegelman, How poets see the world: The art of description in contemporary poetry. Oxford University Press, 2005.

[7] P. B. Shelley, P. Garland, R. Marquard, and G. Watson, A defence of poetry. Haldeman-Julius, 1969.

[8] Yakich M, "What Is a Poem? [Internet]. The Atlantic. Atlantic Media Company," 2013. http://www.theatlantic.com/entertainment/archive/2013/11/what-is-a-poem/281835/ (accessed Sep. 26, 2020).

[9] S. Freud, The future of an illusion. Broadview Press, 2012.

[10] M. H. Abrams and G. Harpham, A glossary of literary terms. Cengage Learning, 2011.

[11] R. A. Harris, "A handbook of rhetorical devices," 1997.

[12] J. Turnbull et al., "Oxford advanced learner's dictionary,” Int. Student's Ed., 2010. 